\title{
Driving SMEs Through Nepotism and Individualism: A Cross Cultural Analysis \& Implications for Enterprise Success in Sub-Sahara Africa
}

\author{
Sunny Ekakitie Emonena ${ }^{1} \&$ Egede Nwawuku Matteo ${ }^{1}$ \\ ${ }^{1}$ Department of Business Administration and Marketing, Delta State University, Asaba Campus, Nigeria \\ Correspondence: Sunny Ekakitie Emonena, Ph.D, Department of Business Administration and Marketing, Delta State \\ University, Asaba Campus, Nigeria.
}

Received: January 30, 2020

Accepted: April 28, 2020

Online Published: May 30, 2020

doi:10.5430/jms.v11n2p29

URL: https://doi.org/10.5430/jms.v11n2p29

\begin{abstract}
As we gravitate deeper into the $21^{\text {st }}$ century, work patterns that drive productivity tend towards teamwork, group specialization, hi-tech and hi-touch processes. This study in acknowledging this new paradigm advocates the adoption of the twin practices of nepotism and individualism for African SMEs. The authors argue that given the peculiar cultural inclinations of Africans where socio-economic activities are woven around family subsistence and individualism in optimizing skills and competences, coupled with readily available labour in most African families; it will be economically wise to drive SMEs set-up and start-ups through family. The authors contend that given the weak capacities of African entrepreneurs competitively, they can become effective if they make a strategic retreat and gradually develop their enterprises via deploying family resources cost effectively to increment capacities for productivity. The paper in examining extant literature evidenced the application of nepotism and individual acumen in the growth of enterprises across notable cultures in the world. Theories of entrepreneurship lending credence to arguments canvassed include Cantillon's theory, the Knightian theory, the individual-opportunity nexus theory and the Mill's theory of individualism among others. These along with empirical studies outcome cited reveal the immense benefits and successes recoverable in the creation/administration of SMEs along these dimensions. In the light of these benefits, the authors suggest among others that policies of government in sub-Saharan Africa should tilt towards incentives for family-patterned SMEs. It also advocates for a platform were innovative SMEs can receive recognition and sponsorship from government and trade/industrial associations. Finally, the paper suggests that SMEs in Africa link up via the Internet with SMEs abroad with a history of family business to learn success and survival strategies and gradually become global players themselves.
\end{abstract}

Keywords: entrepreneurship, nepotism, individualism, family-patterned businesses, global competitiveness

\section{Introduction}

The African continent, particularly sub-Sahara Africa possesses a very interesting case study for researchers both of Western and African orient. Africa has had so much political and socio-economic challenges on account of its interface with Europe, Arabia, India and indeed China. These interfaces have been mainly for economic purposes. Trade and commerce were the main attraction long before politics and religion came. These interfaces make the black continent a hybrid exhibiting complex and multi-dimensional characteristics (Ekanem and Iyoha, 2015; Ekakitie, 2017; Akerele, 2010).

Perhaps, the most potent of these influences are political and economic. With the balkanization of Africa by European powers and its exposure to various political and enterprise models and cultures, it would appear sub-Sahara Africa became overwhelmed by trends it had no control over (Akerele, 2010). Rodney (1976) in chronicling how Europe under-developed Africa eluded to various factors that dislocated the productive fabrics of African economies. One of such strong factors is the destruction of individual and communal efforts in the production of products vide cottage industries like growing cotton, ginning of cotton, clothe dyeing, blacksmithing and iron smelting, animal husbandry etc.

From the unique pyramids of Egypt, the skills and sciences of manufacturing chariots and the gigantic palaces of the Pharaohs and several public buildings down to economic/technological heights which crystalized the vast and legendary empires of Western Sudan, not forgetting the technologies deployed in the Benin and Oyo Empires in iron and bronze works, the African has been strongly wired by the twin work philosophy of individual capacity and 
nepotism. These made cities like Gao and Timbuktu popular as commercial centers of the Western Sudan (1464 - 1754) empires (Ekakitie, 2009). The concept of individualism thus holds much value to the African as it is at the core of his productive ability, his competences and driving passion to achieve his socio-economic goals. Individual competences and beliefs in personal abilities are what distinguishes him intellectually among his peers, earns him his respect, titles and a pride of place in his community (Dauda, 2013; Akerele, 2010). For him, as a member of a thriving and fledging domestic economy, individualism and nepotism were the motivating capsules he needed to announce himself as a person of note.

Today, Western education, coupled with European styled modernization, political adventurism and religious infiltration have all conspired to destroy this well entrenched work culture (Anshika and Nisha, 2016; Adewale, Abolaji and Kolade (2011). More recently neo-colonialism, Western styled globalization and the ICT race have made the African an unwilling participant in a globalization race for which he has no pace and power to catch up; the rules of which he never participated in making and which have no respect for his culture, his belief systems and his domestic productive capability (Akerele, 2010). If anything, many of these evolutions and laws have eroded the belief of 'self-capacity' and 'can do' spirit of the African. What one sees these days is that Africa and most LDCs economies are mere on-lookers as the world, driven by the G7 and the Paris Club nations, gravitates deeper into a sophisticated dispensation where technology, innovations and money power conspire to put the African in a platform of incapacity.

Based on our experiences, we dare posit that nepotism and individualism, contested as they may, still holds a lot of prospect for the African and his enterprise culture. This study argues that nepotism (which means preferring the use of family and relatives) in work processes can be winning strategies to grow SMEs to great heights in sub-Sahara Africa. Western literatures have merely coined the concept to assume a negative taste. We contend that individualism and nepotism have long been winning formulas deployed in creating SMEs in Europe and America and in recent times Japan, Malaysia and Korea. SMEs in these economies have today grown into Multinational (MNCs) and Transnational corporations (TNCs) transforming their economies. We argue that this can also be deployed in Sub-Sahara Africa to create SMEs that can, on the aggregate, emancipate African economies from the shackles of Europe and Asia dominated world trade/commerce. This is more so as the concepts and practices are components of his work values sociocultural experiences and belief systems.

This study projects that nepotism and individualism are key success capsules and strategic initiatives the African entrepreneur need to exploit if Africa ever hope to announce herself one day as a people that have 'arrived' and arrived strong.

\section{Methodology}

The study adopts a theoretical and analytical approach in the administration of the gamut of concepts, constructs implicated in the study and their interrelationships. The theories and anecdotes used also helped procedurally the pattern and framework of the analyses. These approaches have helped provide a strong link knitting together antecedence, correlates and consequences that provides the flow and logic within the theoretical framework that support or oppose the contending arguments. These basic methods along with empirical and practical experiences as evidenced from published studies reviewed in diverse cultures helped bring to fruition the realization of the study objectives.

\section{Literature Review}

\subsection{Nepotism and Individualism - A Conceptual Review}

\subsubsection{Nepotism}

Nepotism is a controversial term that can be defined in various ways and it is also a term that many people have negative associations with (Gustafsson and Norgren, 2014). Nepotism is favoritism granted to relatives or friends regardless of merit. The word nepotism stems from the Latin word- nepos-for nephew, especially the "nephews" of the prelates in medieval times. Again, it is from this word that modern Romanian nepot and Italian nipote, "nephew" or "grandchild" descended (Bush-Bacelis, 2014; CTCweb, 2013). Nepotism describes a variety of practices related to favoritism; it can mean simply hiring one's own family members, or it can mean hiring and advancing unqualified or under qualified family members based simply on the familial relationship (Bush-Bacelis, 2014). Oxford dictionary (2018) aptly defined it as the practice among those with power or influence of favouring relatives or friends, especially by giving them jobs. In actual fact nepotism is an act of appointing one's relatives to the posts where they are not experienced for and outsiders are sidelined. It is mainly caused by selfishness since the person on top wishes to channel the resources to his family and for no one else. Scarcity of jobs also has a role in bringing about nepotism. Nepotism is also tied to discrimination issues of pragmatic concerns. 
Nepotism is often cited as an explanation for the intergenerational transmission of management within family firms. When the founder retires, control of the firm is often transmitted to his heir rather than to a hired professional manager (Borzer and Kuna and Santora 2015; Bertrand and Schoar, 2016). Although family transmission of control might have positive effects in terms of agency costs, the heir might have less talent than a professional manager (Ponzo and Scoppa, 2010).

Attitudes toward nepotism vary according to cultural background. Bailey, Albassami and Al-Meshal (2016) note that in Arab countries nepotism has maintained a strong footing and in many Latin American countries it is accepted as a norm. In Asia, majority of entrepreneurs look to the family, rather than the broader populace for the succession of the business. Uhara (2014) opined that the practice is rampant in Nigeria and has become part of the people's culture which has even assumed a general name of "man-know-man". However, in a country like United States of America, nepotism is a sensitive issue in business and there is a negative attitude towards the practice. Many companies and individuals consider the practice to be unethical, largely due to its conflict with traditional American values of self-reliance and fairness (Bush-Bacelis, 2014).

Nepotism presents ethical dilemmas as few people see it as a problem. Connections, networking, and family - almost everyone has drawn on it as a source of support in job hunting in the private sector. One of the most basic themes in ethics is fairness, stated this way by Aristotle: "Equals should be treated equally and un-equals unequally". Antagonists argue that nepotism interferes with fairness because it gives undue advantage to someone who does not necessarily merit this treatment (Holt, 2015; Nadler and Schulman, 2006). Nepotism is not a new phenomenon in business, but it is of particular interest as the world of business shrinks due to rapid travel and convenience and fast technological communication. As businesses become increasingly globalized, it is crucial to understand how cultural attitudes toward nepotism vary between the different countries in which a business operates. Furthermore, as more families rely on multiple incomes for their standard of living, the ethical and pragmatic considerations regarding nepotism must be carefully negotiated to ensure the most effective overall business strategy. While certain guidelines have been known to effect a smooth incorporation of nepotism into a successful business, there are no definitive strategies. Clearly, however, nepotism can lead to success if applied appropriately, or to disaster if applied without careful consideration of all variables involved (Bush-Bacelis, 2014).

\subsubsection{Individualism}

One of the first social scientists to discuss the phenomenon of individualism in public was the French aristocrat Alexis de Tocqueville. In his second book on Democracy in America (first published in 1840), he argues that individualism manifests itself in that most Americans citizens "feel no longer bound to their fate by a common interest; each of them, standing aloof, thinks that he is reduced to care for himself alone"(Tocqueville, 1998, p. 208). He further notes that individualism is more of "a mature and calm feeling" that originates in the mind just as much as in the heart (Gustavsson, 2008; Tocqueville, 1998). It is also considered to be linked to achievement-values, to the entrepreneurial spirit, the American myth of rugged individualism and self-reliance (Gustavsson, 2008).

Morris, Davis, and Allen (1994) defined individualism as a self-orientation, an emphasis on self-sufficiency and control, the pursuit of individual goals that may or may not be consistent with in-group goals, a willingness to confront members of the in-group to which a person belongs, and a culture where people derive pride from their own accomplishments. In the twentieth century, a cross-cultural researcher, Hofstede (1980) developed a classification of national cultures supported by different dimensions, one of which is individualism versus collectivism. In this article our focus is on individualism excluding its opposite, collectivism (which is the degree to which individuals are integrated into groups). In individualistic cultures ties among people are loose; they place priority on personal goals and to take care of themselves. According to Triandis (2001) they also behave primarily on the basis of their attitudes rather than the norms in their group.

The Hofstede Centre (2015) stressed that the fundamental issue addressed by individualism is the degree of interdependence a society maintains among its members. It has to do with whether people's self-image is defined in terms of "I" or "We". For example, the British are a highly individualistic and private people as children are taught from an early age to think for themselves and to find out what their unique purpose in life is and how they can contribute to society. Similarly, in Germany - considered as individualistic - people stress on personal achievements and individual rights. Germans expect from each other to fulfill their own needs. Group work is important, but everybody has the right to his own opinion and is expected to reflect them. The United States can clearly be seen as individualistic (scoring a 91\%), the "American Dream" is clearly a representation of this. This is the American's hope for a better quality of life and a higher standard of living than their parents'. This belief is that 
anyone, regardless of their status can 'pull up their boot straps' and raise themselves from poverty. (Individualism-clearly cultural, (n.d.); Hofstede Centre, 2015).

Stata (1992) asserted that the primary element of individualism is individual responsibility. Being responsible involves making one's choices consciously and carefully, and accepting accountability for everything one does or fails to do. An integral part of responsibility is productivity. The individualist recognizes that nothing nature gives men is entirely suited to their survival; rather, humans must work to transform their environment to meet their needs. This is the essence of production. The individualist takes responsibility for his own production; he seeks to "earn his own way" to "pull his own weight".

At this juncture, it is pertinent to mention some misconceptions associated with individualism that needs to be pointed out. Individualism is often equated to hedonism and selfishness as found in Gustavsson's (2008) work. Another major misconception is that individualism means isolation - being alone, being outside society. But isolation is not the essence of individualism. In fact the concept of individualism does not make sense in the absence of other human beings. Thus, it is called individualism not because it exhorts the individual to seek a life apart from others, but because it asserts that the individual, and not the group, is the primary constituent of the society. The belief that individualism means being alone leads people erroneously to say that individualism is incompatible with cooperation. Actually, a person who does not listen to others and would rather do things inefficiently as long as it is "my way" is being closed minded. A true individualist wants the best for himself, so he seeks out the best, no matter who is the source.

Below we discuss the areas of linearity between the two concepts as it pertains to supportive theories of entrepreneurship and entrepreneurial development.

\subsection{Theories of Entrepreneurship and Individualism}

\subsubsection{Cantillon's Theory of Entrepreneurship (1755)}

This theory does not view the entrepreneur as a production factor as such but as an agent that takes on risk and thereby equilibrates supply and demand in the economy. Cantillon described an entrepreneur as a person who pays a certain price for a product to resell it at uncertain price, thereby making decisions about obtaining and using resources while consequently assuming the risk of enterprise (Bula, 2012; Holt, 2015). A critical point in Cantillon's argument was that entrepreneurs consciously make decisions about resource allocations. In a neo-classical framework, this function resembles that of the optimizing residual claimant, e.g., the business owner who rents labor and capital from workers and land owners in a world of uncertain demand or production (Bula, 2012).

\subsubsection{The Discovery and Opportunity Theory of Entrepreneurship (Equilibrium Destruction Theory)}

Schumpeter looks at entrepreneurship as innovation and not imitation. The entrepreneur is the prime mover in economic development whose function is to innovate, or to carry out new combinations. Anyone who performs this function is an entrepreneur, whether they are independent or dependent employees of a company (Borzer and Kuna and Santora 2015; Bula, 2012). Accordingly, he viewed entrepreneurship as the process of combining resources in new and different ways to bring ideas to the market. In this sense, Schumpeter's entrepreneur is an innovator- an individual who disturbs the status quo by replacing existing firms or ideas with new firms, products, or processes. This process is a dynamic one, as the entrepreneurs who bring innovations to the market replace businesses (or their products, services, or processes) that are no longer competitive, while simultaneously placing pressure on existing firms to become competitive. This kind of entrepreneurial action causes economic change (Godin, Clemens and Veldhius, 2008). In the Schumpeterian theory, the entrepreneur moves the economy out of the static equilibrium. Marz (1991), states that "Schumpeter hardly denied that the process of accumulation is the ladder to social power and social prestige; but he thought the very mainspring of the exercise of the entrepreneurial function is the powerful will to assert economic leadership. The joy of carrying through innovations is the primary motive, the acquisition of social power a subsidiary to it. The entrepreneur is not (necessarily) the one who invents new combinations but the one who identifies how these new combinations can be applied in production. This line of reasoning implies that a business owner is considered an entrepreneur only if he is carrying out new combinations. The entrepreneur moves the economic system out of the static equilibrium by creating new products or production methods thereby rendering others obsolete. This is the process of "creative destruction "(creating uncertainty) which Schumpeter saw as the driving force behind economic development (Schumpeter, 1949).

\subsubsection{Knightian Theory of Entrepreneurship (Knight, 1921)}

In contrast to Schumpeter, Knight's concept of entrepreneurship relies on his view that there are some people who have unique characteristics that make them entrepreneurs. Entrepreneurship, therefore, is defined by the actions 
taken by these individuals (Knight, 1942). Foresight, managerial ability, confidence in one's judgment, and the disposition to "back it up" with action are characteristics that are unique to entrepreneurs (Knight, 1921; 1964). Those who have superior abilities in these areas will make up a "special social class" of business men who direct economic activity. This view contrasts with that of Schumpeter, who argues that the potential for entrepreneurship exists in everyone (Acs 2015).

Knight specifies three functions of an entrepreneur. The first and primary function is "that of leadership or economic pioneering; it is to initiate useful changes or innovations" (Knight, 1942). The incentive for this function is profit. The second function of an entrepreneur is that of "adaptation to changing conditions." The entrepreneur must be able to "forecast" or anticipate changes in the market in order for his or her business to remain successful. The third function of an entrepreneur is bearing uncertainty. Knight argues that the entrepreneur, as the owner of any enterprise, "places himself in the position to take the consequences of such [unforeseen] changes, (wholly or up to a point) relieving those from whom he hires productive agents of this uncertainty and insecurity" (Knight, 1942). It can be said that Knight viewed an entrepreneur in terms of Risk, Uncertainty and Profit while recognizing the distinction between risk and uncertainty. The latter is uninsurable since it relates to unique events, e.g., a shift in consumer taste. According to Knight, the main function of the entrepreneur is to assume the uncertainty related to these events, thereby shielding all other stakeholders against it. i.e., the entrepreneur exercises judgment over (Bula, 2012).

\subsubsection{The Individual-Opportunity Nexus Theory of Entrepreneurship}

The Shane and Venkataraman (2000) interpretation of the field of entrepreneurship focus on the discovery of opportunities and subsequent exploitation of such opportunities by individuals. However, just because opportunities exist does not mean that everyone perceives them. Only individuals with appropriate qualities will perceive them. Specifically the theory posit that opportunities are objective, individuals are unique, and third entrepreneurs are risk bearing. In its view, opportunity have objective component and these opportunities exist whether or not an individual recognizes them (Holt, 2015; Shane, 2003). Opportunities are derived from the attributes of the industries within which an entrepreneur is contemplating action. The second assumption is that entrepreneurship requires differences in people and these differences manifest themselves in the ability to recognize opportunities (Bush-Bacelis, 2014). Individuals in this view are "alert" to existing opportunities (Kirzner, 1973; Shane and Venkataraman, 2000). The third assumption of this theory is that risk-bearing is a necessary part of the entrepreneurial process. Their theory is inspired by the 'Kirznerian' entrepreneurial discovery process but they emphasize that prior information is needed to complement the new information in the discovery of business opportunities.

\subsubsection{Mill's Theory of Individualism (1993)}

Mill based his theory upon psychological concepts regarding pleasure and pain in a bid to make individualism even more acceptable. This is because earlier conceptions were based on theological and metaphysical grounds (Bishop, 2017). This basis of pleasure and pain placed the theory of individualism within the realm of empirical verification (or falsification). If persons were such that Mill's ethical hedonism motivated their actions, his conception of justice logically followed. Mill likewise rejected the need for a social contract when he stated that;

"A favorite contrivance has been the fiction of a contract, whereby at some unknown period all the members of society engaged to obey the laws, and consented to be punished for any disobedience to them; thereby giving to their legislators the right, which it is assumed they would not otherwise have had of punishing them, either for their own good or for that of society ... I need hardly remark, that even if the consent were not a mere fiction, this maxim is not superior in authority to the others which it is brought in to supersede"..

Mill felt the "fiction" of a social contract did nothing to solve the problems it had been created for. Mill's belief that we can only interfere in the affairs of another when they do harm to others means that the social contract would be null and void only when least harm were done.

Further, Mill clearly rejects the concept of having some contract be binding which was signed ages ago, if at all. Therefore, rather than base his conception of individualism on theological, metaphysics or contractual foundations, he instead girds it with psychology. The result is his theory of individualism. Mill believed that individuals were the arbiters of their own actions and so he is considered to be one of the strongest proponents for liberalism, checked only by his harm principle.

These theories and conceptions have many lessons for SMEs and their owners in Africa. Let us peruse some research outcome tangential with these theories. 


\subsection{Review of Empirical Studies}

Assessing the relevance of culture on entrepreneurial behavior, Thomas and Mueller (2000) tested two of Hofstede's (1980) cultural dimensions, individualism and uncertainty avoidance, on entrepreneurial potential of a sample of 1,800 individuals from nine different countries. The results of the study gives empirical evidence that on the one hand, individualistic cultures have a more internal locus of control than collectivist cultures, and on the other hand, an internal locus of control combined with innovativeness is more found in individualistic cultures with a low uncertainty avoidance than in collectivist cultures with a high level of uncertainty avoidance. Exploring the synergies between entrepreneurship and innovation, Elbaz, Binkour and Majdouline's (2013) empirical study of nine Moroccan firms revealed that:

1) Entrepreneurship and innovation are positively related to each other and interact to help an organization to prosper;

2) Entrepreneurship and innovation are complementary, and a combination of the two might be vital to corporate success and sustainability in today's dynamic and changing environment;

3) Entrepreneurship and innovation are not confined to the initial stages of a new venture; rather, they are dynamic and holistic processes in entrepreneurial and innovative organizations.

Strands of studies indicate that entrepreneurial initiatives especially innovation, risk bearing, employment creation, new opportunities identification and the commercialization of results of inventions have indeed contributed to the prosperity in many regions of the world (Schumpeter, 1949; Ukaegbu, 2000; Benzing-Chu, and Kara, 2008). In Africa, the contribution of entrepreneurship cannot be underscored. For instance, Ghanaian micro-enterprises employ less than 5 people, yet accounted for 70 percent of country's workforce (Government of Ghana, 2013; World Bank, 2016). Similarly, Kenya's private SMEs sector employed 3.2 million people and contributed $18 \%$ to the nation's GDP (OECD, 2013). Stel (2017) in a comparative study on the entrepreneurial aspect of total entrepreneurial activity rates and business ownership rates for G7 countries (i.e. U.S., Canada, Italy, U.K., Germany, France and Japan), findings revealed that entrepreneurial activity is highest in the United States. This reflects the dynamic character of the US economy as many individuals are in the process of starting a new business or are the owner/manager of a young business (younger than 35 years). However, while there are relatively many new businesses in the United States (high entry rate), there is also a relatively high exit rate, as many of the new firms do not survive. In contrast, while Italy has the highest business ownership rate, the low entrepreneurial activity rate indicates that there is not much development in the composition of the business population. The case of Africa is underscored by high attrition occasioned by unhealthy competitive tendencies from abroad and poor infrastructure.

Business regulatory environment play a pivotal role in increasing the level of entrepreneurial activity. A $28 \%$ increase in Brazil's entrepreneurship activities between 2006 and 2011 is attributed to its well-managed government policies to stimulate and support the development and growth of businesses, as well as numerous business policy reforms that have focused on making it easier to start businesses (Simrie et al., 2011). In contrast, Global Entrepreneurship Monitors (GEM) surveys from 2002-2011 revealed consistently low levels of entrepreneurial activities in South Africa (Simrie et al., 2011). Empirical evidence to support this contention was provided by Musara and Gwaindepi's (2014) study which indicates that bureaucracy, corruption, policy credibility, policy compliances and labour restrictions are the chief factors within the business regulatory environment that affect the process of starting new businesses in South Africa. Furthermore, the study also found a positive and significance correlation between bureaucracy and corruption. These show the importance of the business regulatory environment in increasing entrepreneurial activities of a nation. In Africa regulatory activities are low and most SMEs and entrepreneurial endeavours are unclassified and unorganized (Ekakitie, 2019).

Jin et al's (2010) comparative analyses of human capital elements, which significantly influence enterprises' growth performance between high-tech and traditional enterprises in China, shows that human capital elements of the same entrepreneur have different impacts on the performance of business growth in different industries and innovation and business growth performances from a high-tech enterprise have greater reliance on human capital of entrepreneurs than traditional industries. From the above empirical analyses certain facts and accompanying logic inevitably leads to the following conclusive results as presented below.

\section{Results and Findings}

The lessons we draw from the concepts and practices of individualism as reviewed in literature as well as theories above also have their philosophical undertones grounded in African communalism system - a core belief and work system in Africa. The attempt at justifying their use has the study appraising their seeming constraints (as may be 
viewed from Western perspective) but contends that they indeed birth good prospects and yield results in innovativeness of SMEs operators. They also aid in critical areas of start-ups, risk taking, innovativeness and general administration in closely knit patterns of work and existence. Their adoption is portrayed as a propeller of sustained socioeconomic development on the continent. Further results and benefits in their application are articulated inter alia:

- Funding: Most African entrepreneurs have a fundamental problem of raising capital for operating SMEs. Engaging employees in the formal strict sense may pose drawback as payments of wages may frustrate start-ups. Nepotism can thus provide a veritable option that is cost effective.

- Ease of managing worker attitude: It can be very convenient managing individuals and persons whose attitude one has already known. Furthermore, the knowledge that workers are of one's own family of origin would elicit cooperation and knitting of minds, creating synergy to aid productivity.

- Use of local technology: The use of local craft and techniques can best be deployed to aid productivity is such closely knit systems. For instance, among the Anioma people of Delta State of Nigeria, clothe making using sticks to gin cotton into yarn, the evolution of techniques of making white Akwuocha fabrics for special ceremonies; the technique of dyeing clothe and making of Kampala dresses are a direct results of putting local technologies to profitable and competitive use.

- Market development: Most African markets have strong potentials on account of an increasingly growing population. It is therefore not a problem having customers to buy and absorb the local manufactures or produce. Besides, with nepotism and individualism new markets and new uses for products can be easily developed.

- Evolvement of skills: Skills and core competencies reside in individuals who work hard to invent and develop them. Local cottage industries provide veritable ground for grooming talents to brilliance, an integral component of modern training and skill development system. Skills and competitions in most Sub-Saharan States have evolved cottage industries that now support local economies.

\subsection{Other Lessons for African Entrepreneurs}

Nepotism has resulted in successes of entrepreneurs across the globe from which SMEs and their operators in Africa can take a cue. For instance, many listed firms in Malaysia are owned or controlled by family and these companies appear to be inherited by their own descendants (Ibrahim and Samad, 2010). Malaysian-born magnate and billionaire Robert Kuok Hock Nien (world's $39^{\text {th }}$ richest person according to the Bloomberg Billionaire Index), through the Kerry Group limited which he chairs and controls, listed enterprises with a total market value of about $\$ 40$ billion. Relatives run the most important parts of the Kuok businesses. Kuok's second son, Kuok Khoon Ean, heads Shangri-La Asia hotels chain which the family owns 50 percent. A nephew, Kuok Khoon Hong, chairs Wilmar International, the world's largest listed palm oil company with a market value of almost $\$ 20$ billion. His daughter Kuok Hui Kwong, is the Executive Director of SCMP Group Limited, publisher of the 109-year-old south China Morning Post (Bloomberg, 2013). Other key family firms in Malaysia include IOI Group, Hong Leong Group and Berjaya Group (Ibrahim and Samad, 2010).

When practiced fairly, nepotism can be a true asset. Nelton (1998) citing the example of Thomas International Publishing Company New York in 1998, there were seven third-and fourth-generation family members working for the company.

"The third-generation President, Tom Knudson, encouraged nepotism among their independent sales contractors because he believed it resulted in high performance, stability, and long-term commitment."

Kaydo (1998) also writes that nepotism may be viable in several positive dimensions. For example, a top salesperson's relative may have many of the same qualities that make the representative successful. Recruiting family members can therefore boost both performance as well as retention. For instance, one senior contractor began working for Thomas in 1940. By 1998 his wife and three of his adult children (two daughters and a son) all worked for the company. The son encountered a challenge when calling on a client at odds time with the senior contractor. He easily and politely diffused the situation using the diplomacy techniques he had gleaned from his father, the very senior contractor the client disliked, and gained a larger-than-usual sale.

"Nepotism is also dominant in Indian business and even arts.The largest corporations in India are in some sense "family owned", Reliance Industries Ltd, being the most interesting example. The company was co-founded by Dhirubhai Ambani and his cousin in the 1960s. After the founder's death the company was 
inherited by his two sons Mukesh and Anil Ambani. A succession war ensued and the matter was finally settled in court. Today, Reliance is the most profitable company in India" (India Times, 2015).

The Kapoor Family is the most obvious example of nepotism in Indian film industry as young actors find it impossible to get an opportunity unless they are related to a prominent figure in the film industry, politics or privileged in some other way. A review of how nepotism has impacted on business success will not be complete without mentioning Saudi Arabian Alkhorayef Group.

"The group was founded in 1957 by the late Abdullah Ibrahim Alkhorayef who passed the banner to his children who developed the company, modernized it and spread its activities worldwide. Today, under the leadership of third-generation Saad Abdullah Alkhorayef, the Riyadh-based firm has achieved excellence on agricultural market, strengthened its international presence with operations in more than 40 countries" (CampdenFB, 2013).

Individualism as a concept and practice in business also has achieved a string of entrepreneurial successes over time. Individualism as the second dimension of the study has also transcended in establishment of businesses that are well-known for creating incremental wealth for the society at large. Germany, a nation considered as individualistic with a relatively high score (67) on the scale of Hofstede (individualism-clearly cultural, n.d.) and the industrial power house of Europe boast of one of these self-made entrepreneurs.

“..Andreas Von Bechtolsheim from Bavaria began to experiment with electrics and electronics at a tender age which led to the design of a controller for industrial operations that allowed him to finance his studies. He later designed the SUN workstation which in 1988, after only 6 years in the market, was worth over \$1 billion USD. He is also known as one of the first investors in Google. His other investments include Tasmania network systems, Brightmail, Brocade and Mirapoint." (Brown, 2012).

Another case in point is Robin Li, the founder and CEO of China's largest online search company Baidu. Li made his billions by building a pioneer company in China's highly competitive Internet market, where most companies fail to monetize their business model. Baidu's revenues have been growing in leaps and bounds; reaching $\$ 4.17$ billion in 2013 (Mourdoukoutas, 2013). Before the birth of Baidu, Li has helped develop a software program for online edition of the Wall Street Journal, the Rankdex site-scoring algorithm for search engine page ranking and also worked on improving algorithms for search engines

Sir Richard Branson from Britain, one of the most individualistic societies in the world, epitomizes self-made serial entrepreneur. At the age of sixteen his first business venture was a magazine called Student. Then in 1970, he founded a mail-order record company. Within a year he had opened his first shop on London's Oxford Street -Virgin Records. Virgin has now become a brand which now covers everything from telecommunication to space tourism (Boyce, 2014; Mckenzie, 2013).

In Nigeria, the Ibru and Dangote family have become a legend of some sort in individualism as it pertains to entrepreneurship. They have virtually become household names announcing Nigeria to the outside world. Other SMEs on the African continent have a lot to glean from them.

\section{Conclusion}

The study has critically discussed the concepts of individualism and nepotism as it patterns to growing SMEs in Sub Sahara Africa. It has x-rayed the various grounds that warrant its use and a cross cultural analysis of how its use has become very profitable across certain cultures. The lessons African entrepreneurs can draw have been highlighted in this discourse. Ipso facto, individualism is not isolationism as some critics may see it; it is not about an SME operating alone or being in an island of its own. Individualism is developing and relying on core competencies and own capacities to dictate the strategic direction to go and having others follow. It is about being the leader in one's own industry of competition via innovations, evolutions of skills and competencies that cannot be copied competencies that can become patents. It is about pursuing and showcasing an enterprise' own dream within the context of a competitive market environment and a set vision of being the best.

Because individuals constitute the primary unit of society not the group; the concept of individualism precludes the narrow definitions of an individual entrepreneur not desiring to associate, cooperate or compete with others - it defines SMEs whose drivers want to distinguish themselves as entrepreneurs of note with distinctive pedigree for value delivery. A true individualist is one who seeks out the best and wants to be the best.

As a corollary, nepotism is not absolute in real terms. It does not mean that talents and skill or other initiatives cannot be tapped from elsewhere to grow enterprises. Nepotism is about 'self-preservation' on key success factors that give 
competitive edge in industries of operations. Unique production formulas, patents and competencies that should remain business secrets for success and longevity are best protected vide nepotism. It gives credence to moulding and shaping positive attitudes and work behavior that improves workers cohesion, can do spirit, esprit de corp., etc. Henri Fayol's 14 Principles of Management advocate the twin concepts of 'unity of command' and 'unity of direction' without which an enterprise may not be effective. Nepotism and individualism galvanizes these as the spirit of 'ownership' permeates the enterprise. It also provides the training ground for development of all cadres of management - from shop floor to top management. People rise up the ladder based on skills, experience, length of time and commitment they have put into serving the enterprise. Thus, for one to be a unit or divisional manager in most Japanese family enterprises ones' grand-parents and parents must have worked and risen up the ladder over the decades. It is not just by academic brilliance. This underscores commitment and loyalty to the organization and secures a life-time service whose dividends are invaluable.

Businesses that are family owned procure strategic alliances with other enterprises of like or different nature, but have synergy of sorts. Hence managerial and operational ties can be strengthened via these strategic alliances (Devi, 2017; Di Paolo, 2016). Thus, one enterprise secures certain interest of the other and receiving a service or product of value in return. This could be capacity for effective distribution chain management or providing insurance services for a different organization and/or out-sourcing the making of a particular component part to another family enterprise. Thus, the commanding heights of an economy can be supported by a network of family businesses. The ideology is that of 'standing together' and 'supporting one another' for economic survival. The Kareitsu businesses in Japan are built around this philosophy and they constitute the hub of the Japanese economy. Africa SMEs have lots of lessons to draw from these enterprises.

\section{Recommendations}

In the light of study discourses the authors make the following recommendations:

- There is the need for government policy to encourage the formation of SMEs that are oriented towards family businesses, taking advantage of available idle family labour and skills to kick-start enterprises especially at formation stage. These types of family businesses can enjoy patronage from government via free CAC registration, training and development programmes in addition to financial incentives such as reduced interest rates and grants.

- The Ministry of Trade and Commerce in collaboration with Trade and Industry Associations should create necessary platforms and workshops for individuals and SMEs with proven individualistic tendencies in special innovations/creativity, to showcase their inventions and core competencies for sponsorship.

- SMEs patterned along family lines have golden opportunity vide current ICT and internet resources to link up with SMEs with like family businesses in advanced economies to learn the intricacies involved in establishing, and running family-based enterprises to success. This can open up a whole lot of opportunities for SMEs in Sub-Saharan Africa to achieve strategic alliances and become enterprises of note in their domestic business environments with a global focus.

- There is the urgent need to strengthen existing institutions and government agencies to embark on aggressive extension services for SMEs that are patterned and formed along family coalitions and individual prowess (Like the Kereitsus businesses of Japan) with the objective of rapidly growing them into national and global reckoning.

\section{References}

Adam, B. (2003). In Praise of Nepotism: A natural History. New York: Doubleday.

Adewale, O., Abolaji, A. J., \& Kolade, O. J. (2011). Succession Planning and Organizational Survival: Empirical Study of Nigerian Private Tertiary Institutions. Serbian Journal of Management, 6(2), 231-246.

Akerele, A. (2010). Black Restoration is a Black Responsibility: Nigeria and the Black Leadership Imperative. Inaugural Lecture Series 54, University of Benin, Benin City.

Anshika, S., \& Nisha, A. (2016). Succession Planning in MSMEs: Emergence, Importance and Process. IOSR Journal of Business and Management, 18(6), 01-09.

Bailey, A. A., Albassami, F., \& Al-Meshal, S. (2016). The Roles Of Employee Job Satisfaction And Organizational Commitment in The Internal Marketing Employee Bank Identification Relationships. International Journal of Bank Marketing, 34(6), 821-840. 
Benzing, C., Chu, H. M., \& Kara, O. (2008). Entrepreneurs in Turkey: A Factor Analysis of Motivations, Success Factors, and Problems. Journal of Small Business Management. 47(1), 58-91. https://doi.org/10.1111/j.1540-627X.2008.00262.X

Bertrand, M., \& Schoar, A. (2016). The Role of Family in Family Firms. Journal of Economic Perspectives, 20(2), 73-96.

Bishop, P. S. (2017). Three theories of Individualism. Graduate theses and dissertation. Retrieved from http://www.scholarcommons.usf.edu/etd

Boyce, L. (2014). The top 25 Rags-to-riches Entrepreneurs: Sir Philip Green, Mike Ashley and Sir Richard Branson top list of those who started with small sums but built business empires. This is MONEY. Retrieved from http://www.thisismoney.co.uk

Bozer, G., Kuna, S., \& Santora, J. (2015). The Role of Leadership Development in Enhancing Succession Planning in The Israeli Nonprofit Sector. Human Service Organizations Management, Leadership and Governance, 39(5), 492-508.

Brown, J. (2012, December 17). The top 10 European Self Made Entrepreneurs. Addicted2success. Retrieved from http://www.addicted2success.com/news/

Bula, H. O. (2012). Evolution and theories of entrepreneurship: A critical review on the Kenyan perspective. International Journal of Business and Commerce, 1(11), 81-96. Retrieved from http://www.ijbcnet.com

Bush-Bacelis, J. (2014). Nepotism. In Reference for Business. Retrieved from http://www.referenceforbusiness.com/management/Mar-No/Nepotism.html

CampdenFB. (2013). Top 50 Family Business Leaders 2013. CampdenFB. Retrieved February 21, from http://www.campdenfb.com/article

Cantillon, R. (1755). Essai sur la Nature du Commerce en Générale (H. Higgs Ed.). London: Macmillan, 1931.

CTCweb. (2013). Article nepos. CTCweb Glossary. Retrieved from http://www.ablemedia.com

Dauda, A. (2013). Business Continuity and Challenge of Succession in Nigeria: What happens when the CEO Leave?. Journal of Business and Management, 8(4), 59-65.

Devi, S. (2017). Impact of Employee Engagement on Organizational Performance: A study of Select Private Sector, IMS Business School Presents Doctoral Colloquium - 2017.

Di Paolo, A. (2016). Endogenous Occupational Choices and Job Satisfaction among recent Spanish PhD Recipients. International Journal of Manpower, 37(3), 511-535.

Ekakitie, E. S. (2017). Development Initiatives (DI) and Peace Building: Nature, Scope \& Mechanics. Society for Peace and Strategic Studies, University of Ibadan, Zenith Books.

Ekakitie, S. (2009). Management: A Behavioural and Strategic Approach. Bob Peco Printing and Publishing Company, 47 Aruosa Street Benin City.

Ekanem, O. T., \& Iyoha, M. A. (2015). Microeconomic Theory (3rd ed.). Benin City, Mareh Publishing.

Elbaz, J., Binkour, M., \& Majdouline, I. (2013). Innovation and Entrepreneurship: An empirical study of Moroccan firms. Conference Paper, EMNet. Retrieved from https://www.emnet.univie.ac.at

Godin, K., Clemens, J., \& Veldhuis, N. (2008). Studies in Entrepreneurship markets: Measuring entrepreneurship, conceptual frameworks and empirical indicators. Vancouver: Fraser institute.

Government of Ghana. (2013). National Medium Term Private Sector Development Strategy, 11(4), 56-78.

Gustafsson, C., \& Norgren, H. (2014). Nepotism Perceived by Managers in Northern Sweden-An explorative study on attitudes towards nepotism and its usage (Bachelor Thesis). Umea School of Business and Economics, Umea, Sweden.

Gustavsson, G. (2008). What Individualism Is and Is Not. Workshop paper, presented at NOPSA conference 2008, Tromso.

Hofstede Centre. (2015). Strategy, Culture, Change. Retrieved from http://www.geert-hofstede.com

Hofstede, G. (1980). Culture's Consequences: International Differences In Work-Related Values. Beverly Hills, CA: Sage Publications. 
Holt, D. (2015). Entrepreneurship: New Venture Creation (2nd ed.). New Delhi: Prentice-hall of India Pvt Ltd.

Ibrahim, H., \& Samad, F. A. (2010). Family Business in Emerging Markets: The Case of Malaysia. African Journal of Business Management, 4(13), 2586-2595. Retrieved from http://www.academicjournals.org/AJBM

Jin, Z., Huixin, Y., \& Ruizhan, L. (2010). Empirical Research on Private Entrepreneurs, Human Capital and Enterprises' Growth Performance. A Comparative Analysis between High-Tech Enterprises and Traditional Enterprises. Journal of Chinese Entrepreneurship, 2(2), 175-195. https://doi.org/10.1108/17561391011051153

Kirzner, I. S. (1973). Competition and entrepreneurship. Chicago: University of Chicago press.

Kirzner, I. S. (1979). Perception, Opportunity, and Profit: Studies in the theory of entrepreneurship. Chicago: University of Chicago Press.

Kirzner, I. S. (1997). Entrepreneurial Discovery and Competitive Market Process: An Austrian Approach. Journal of Economic Literature, 35(3), 60-85.

Knight, F. (1921). Risk, Uncertainty and Profit. Boston, MA: Houghton Mifflin.

Knight, F. (1942). Profit and Entrepreneurial Functions. The Journal of Economic History 2(supplementary December), 126-132.

Mckenzie, S. (2016). Back to the Future for Richard Branson's retro 80s speed boat. CNN. Retrieved from http://www.edition.cnn.com/2016/04/25/business/

Mills, J. S. (1993a). A System of Logic. New York: Bantum Classic.

Mills, J. S. (1993b). Utilitarianism. New York: Bantum Classic.

Morris, M., Davis, D., \& Allene, J. (1994). Fostering Corporate Entrepreneurship: Cross-Cultural Comparisons Of The Importance Of Individualism Versus Collectivism. Journal of International Business Studies, (First Quarter), 65-89.

Mourdoukoutas, P. (2013, October 27). The Rise of Self-Made Billionaire Entrepreneurs in China, and what it means for the future of Chinese corporation. Forbes Magazine. Retrieved from http://www.forbes.com/sites/panosmourdoukoutas/

Musara, M., \& Gwaindepi, C. (2014). Factors within the Business Regulatory Environment Affecting Entrepreneurial Activity in South Africa. Mediterranean Journal of Social Sciences, 5(6), 109-116. https://doi.org/10.5901/mjss.2014.v5n6p109

Nadler, J., \& Schulman, N. (2006). Favoritism, Cronyism, and Nepotism. Working Paper, prepared for Markkula Centre for applied Ethics, Santa Clara University. Retrieved from http://www.scu.edu/focusarea/

Nelton, S. (1998). The Bright Side of Nepotism. Nation's Business, 86(5), 72.

OECD. (2013). Economic Wellbeing Framework for Statistics on Distribution of Household Income, Consumption and Wealth. Paris: OECD Publishing. https://doi.org/101707/9789264194830-J-eni.oct 2013

Oxford Dictionary. (2018). English Dictionary. https://doi.org/10.1093/acref/9780199571123.007.001

Ponzo, M., \& Scoppa, V. (2010). A simple model of nepotism. Working Paper N.17-2010. University of Calabria. Retrieved from http://www.ecostat.unical.it

Rodney, W. (1976). How Europe Underdeveloped Africa. Bogle-L'Ouveture Publications, 131 Coldershaw Road, London W. 13.

Schumpeter, J. (1949). Economic Theory and Entrepreneurial History. In R. Clemence (Ed.), Essays on Entrepreneurs, Innovations, Business Cycles, and the Evolution of Capitalism (pp. 253-271). Transaction Publishers.

Schumpeter, J. (1983). The Theory of Economic Development: An Inquiry into Profits, Capital, Credit, Interest, and the Business Cycle. Translated by Redvers Opie. New Brunswick: Transaction Books.

Shane, S. (2003). A General Theory of Entrepreneurship. The individual-Opportunity Nexus. Massachusetts: Edward Elgar publishing, Inc.

Shane, S., \& Venkataraman, S. (2000). The promise of entrepreneurship as a field of research. Academy of Management Review, 25(1), 217-216. 
Simrie, S., Herrington, M., Kew, J., \& Turton, N. (2011). Global Entrepreneurship Monitor 2011 South Africa. Retrieved from http://www.gemconsortium.org/docs/download/2313

Stata, R. (1992). What is Individualism? Introductory Speech Delivered at MIT radicals for capitalism. Retrieved from http://www.mol.redbarn.org/objectivism/writing/RaymieStata/whatisindividualism.html

Stel, A. J. (2017). Entrepreneurhsip and Economic Growth. Some Empirical Studies. Rotterdam: Tinbergen institute.

Thomas, A. S., \& Mueller, S. C. (2000). A Case for Comparative Entrepreneurship: Assessing the relevance of culture. Journal of International Business Studies, 31(2), 287-302.

Tocqueville, A. (1998). Democracy in America. Ware- Wordsworth edition.

Triandis, H. C. (2001). Individualism -Collectivism and Personality. Journal of Personality, 69(6), 907-924.

Uhara, E. E. (2014, January 21). The Effects of Nepotism in Nigeria. News 247. Retieved from http://www.news247.com.ng

Ukaegbu, C. C. (2000). Working Conditions and Employee Commitment in Indigenous Private Manufacturing Firms in Nigeria: Managing Business Organizations For Industrial Development. Journal of Modern African Studies, 38(1), 295-324.

World Bank. (2016). Ghana: World Bank Support Micro, Small and Medium Enterprises (MSME). Development. News Release No. 2016/230/AFR. 